\title{
LOST NARRATIVES AND HYBRID IDENTITIES IN THE INDIAN OCEAN: AFro-
} ASIANS

\author{
SHIHAN DE SILVA \\ Institute of Commonwealth Studies, University of London \\ shihan.desilva@sas.ac.uk
}

Received: 20-08-2016

Accepted: 17-12-2016

\begin{abstract}
The voluntary movement of Africans was concurrent with their involuntary uprooting, driven by the slave trade. Trade, colonisation and slavery have been drivers of migration, interconnecting people of diverse ethnicity globally. Afro-Asian communities are both historic and contemporary and, whilst Afro-diasporic communities in the Atlantic World are well recognised, the diasporas in Asia have only become visible in the last decade. Assimilation to the diversity of the Indian Ocean has contributed to this invisibility. With the loss of patronage due to changing political scenarios, African migrants have become disenfranchised. The dynamics of their identity, shaped by strong cultural memories bring out their African roots. This paper argues that diasporic consciousness of AfroAsians is expressed through their strong cultural memories. As people with dual belongings, identifying with both the homeland and the hostland, Afro-Asians are able to reconcile their hybrid identities. With the movement of Afro-Asians from the peripheries their subaltern voices are beginning to be heard. Their eclipsed histories and lost narratives are challenging the Atlantic model of African migration.
\end{abstract}

KEYWORDS: African diaspora, Indian Ocean, Hybrid Identities, Homeland, Hostland, Afro-Asians.

\section{RESUMEN Historias perdidas e identidades híbridas en el Océano Índico: Los afro-asiáticos}

El movimiento voluntario de africanos fue simultáneo al desplazamiento involuntario debido a la trata de esclavos. La trata, la colonización y la esclavitud han sido factores de migración, interconectando globalmente gente de diferentes etnicidades. Las comunidades euroasiáticas son tan históricas como contemporáneas. Mientras que las comunidades afrodiaspóricas en el Atlántico son bien reconocidas, las diásporas de Asia se han visibilizado solo en la última década. La integración de la diversidad en el Océano Índico ha contribuido a su invisibilidad. Con menos patronazgo debido al cambio de escenarios político, los migrantes africanos fueron privados de derechos. La dinámica de su identidad, formada por una memoria cultural muy fuerte saca a relucir sus raíces africanas. Este ensayo argumenta que la conciencia diaspórica de los afro-asiáticos es expresada a través de su gran memoria cultural. Los afroasiáticos, como personas con doble identidad, se identifican tanto con la patria como con el país de acogida, son capaces de reconciliar su identidad híbrida. Con el movimiento de los afroasiáticos desde la periferia, sus voces están empezando a ser oídas. Sus historias perdidas y eclipsadas están desafiando el modelo atlántico de la migración africana.

PalabraS ClaVe: Diaspora africana; Océano Índico; identidades híbridas, patria; afro-asiáticos 


\section{Introduction}

The Indian Ocean is a giant waterway connecting Africa and Asia and has been a space for exchanging goods and ideas. Afro-diasporic communities are part of this process but their existence tends to surprise both academics and the populous at large. This paper seeks to understand the rationale for the invisibility of these diasporas. Afro-diasporic communities have been lost due to the antiquity of the movement, processes of acculturation and indigenisation and, the diversity of the region. The paper focuses on Sri Lanka and India in order to examine how diasporic consciousness is evoked through cultural memories. This reinforced the hybrid identity of Afro-Asians and is re-established through the creativity of the diasporic communities and expressed through song and music. Scholars (Campbell 2006) question whether Afro-Asians could even be considered a diaspora as their epistemologies were based on established notions of diaspora which as John McLeod (2008) points out precludes even the Jews being a diaspora. Lack of archival records should not govern scholars in assessing the history and heritage of a community. Instead they should draw on alternative methods. The long duration of African migration to the East and the tradition of accepting migrants led Afro-Asians to assimilate into local cultures. Those who have been marginalised are lost in the diversity of the region. This paper argues that beneath the veneer of assimilation lies a desire to be different forced through to the surface by the power of their musical memories.

The better known African diasporas in the Americas and Europe are not considered in this paper. Search for global African diasporas by the African Union and the United Nations has heightened awareness of those scattered Afro-Asian communities who have merged into the hinterlands due to the process of indigenisation. Although a link with the geographical entity that was left behind could not be maintained due to the nature of forced migration and the dynamics of the African continent, recent visits to these communities by Africans and also invitations from Africans for Afro-Asians to perform their traditions, has ruptured epistemologies. Afro-Asians in the cosmopolitan cities are taken for African visitors, yet when they speak in a local language - Gujarati, Sinhala, Kannada - local Asians are shocked. Most Afro-Asians have now lost their ability to speak African languages -- KiSwahili, Emákhuwa - which reflects the antiquity of their migration to Asia. Some learnt the lingua franca of the day - Indo-Portuguese of Ceylon (Sri Lanka Portuguese) - which reveals their patrons (de Silva Jayasuriya 2008). As intermarriages dilute the physiognomic characteristics, 
their African-ness emerges through their continuing cultural practices, which is perhaps due to their resistance to total conformity and expression of identity.

The African diaspora is built on the triadic relationship between Africa as Homeland, Africans and their descendants and an adopted residence or home abroad (Harris, 2003). At a conference of the UNESCO Slave Route Project in 2003, Joseph Harris, an African American Historian, suggested that the silent histories of Afro-Asians could be unlocked by those who spoke their languages. Given the diversity of Asia, a team of scholars with numerous linguistic skills are needed in order to avoid oral histories being lost in translation. Tapping into memories of the diasporists could be a way of mapping their routes to their Asian hostlands. Identifying migration streams and points of origin is challenging. Historical records are inadequate and cultural memories are revealing (de Silva Jayasuriya, 2010). African diaspora researchers encounter numerous problems which were well articulated at a UNESCO conference in Haiti by Hubert Gerbeau, a French Historian:

A historian studying the African diaspora should also be an archaeologist, ethnologist, specialist of oral traditions, a biologist, a linguist and a psychiatrist (my translation: Gerbeau 1978).

An interdisciplinary approach is clearly the way forward. Recording oral histories and conducting anthropological and ethnomusicological studies before memories fade away should be priorities on the researcher's agenda. But field studies do not reveal historical diasporas that have assimilated or disappeared. In Sumatra, Java, Macau, Malacca, for example, historical African communities became lost with the changes in political scenarios (de Silva Jayasuriya, 2010). Today, Afro-Asians are lost in the diversity of the cosmopolitan cities and the invisibility of the hinterlands. Intermarriage with locals and merging with groups whose socioeconomic plight is similar to theirs has also exacerbated the problem. Several generations were born locally and Afro-Asians are now indigenised and are nationals of their Asian host countries.

In the Middle East and South Asia, a steady and undramatic demand for personal slaves, sailors and soldiers was partially met by forced migration of Africans before the sixteenth century (Alpers, 2003: 27). From the sixteenth century onwards, the European powers - Portuguese, Dutch, French, and British - were an added source of demand for the 
Indian Ocean slave trade. Within colonial narratives and records, captives are visible en bloc, as anonymous sailors, soldiers and servants. In Goa, for example, the Portuguese employed (African) slaves as sailors on the ships of the carreira da Índia (Capela, 2002: 28-29).

De Silva (1972: 232) states that the Kaffir contingent in the Portuguese army in Sri Lankan records appeared after 1631. The cost (salaries paid, clothing and rice rations) of maintaining two hundred and eighty African soldiers in Sri Lanka is recorded (de Silva, 1972: 231-232). According to Chandra de Silva (1972: 188), the Kaffirs were Portuguese African captives trained in war. Kaffir (cafre in Portuguese is an Arabic borrowing - qafr (Arabic) meaning 'non-believer') has no negative connotations in this context.

The four thousand strong force that Dom Jorge de Almeida, Captain-General of Ceylon (1631-34) took from Colombo to Malwana on 4 January 1632, included one third Kaffirs and Canarese; the remainder were Portuguese and lascarins (Sinhalese militiamen) (de Silva 1972: 133). In the following year, on 22 November 1633, when Diego de Mello de Castro arrived in Colombo as Captain General (1633-35) he mustered a thousand Kaffirs, Canarese, four hundred Portuguese and five thousand lascarins (local soldiers) for his mobile army (de Silva, 1972: 141). During his second term of office (1636-38), Captain-General Diego de Mello de Castro's army consisted of three hundred Kaffirs, seven hundred Portuguese, two hundred Canarese and five thousand lascarins and a regiment of topazes when he invaded Kandy in May 1638 (de Silva, 1972: 154). Topazes were half-caste claimants of Portuguese descent who were also Christian (Hobson-Jobson, 1903). The Portuguese period came to an end in 1658 after a twenty year struggle with the Dutch who routed them from the island. In 1796, the British took control of the coastal areas from the Dutch in order to keep the French at bay. The three European powers engaged Africans in many tasks ranging from the military to servants.

Free and forced migrants are not easily distinguishable. Slavery and serfdom are entangled with captives categorised together with servants. Whenever captives are personalised, their African identity is erased by the Arabic or Western names given in captivity (de Silva Jayasuriya, 2017a). Few African names have been retained but ultimate ethnic origins are not specified; the port of embarkation is taken as the ethnic origin of captives. Lack of ethnolinguistic detail and cultural traits in the records is perhaps to be expected but makes identification more problematic. Even when origins are listed, changing boundaries of African territories over the centuries enhances the blurred ethnicity. But financial drivers behind trade and colonisation dictated that captives were documented when there was a cost implication. In the East India Company Sumatra factory manuscripts in the 
British Library which I consulted, emancipated slaves receiving pensions are listed with name and age (de Silva Jayasuriya 2010, de Silva Jayasuriya 2017a).

Ancient trade networks and the diversity of Asia were catalysts for assimilation of diasporic cultures. Mingling of peoples led to a cultural mosaic in the region. Trade routes which are older than colonisation reveal the migratory routes of the captives. But the borderline between descendants of captives and free migrants is not always clearly defined. Intersection of free and forced movement is memorialised in Janjira, an island base off western India for African traders since the thirteenth century. From the sixteenth century, Janjira became the powerbase for Africans who ruled the Indian States of Janjira and Sachin until they became part of the Indian Union after independence. Descendants of these elite Africans continue to live in India but are now only a few hundred in number (Robbins and McLeod, 2006).

The first reference to the slave trade in eastern Africa is documented in a guide for Greco-Roman merchants - The Periplus of the Erythraen Sea - written in the first century A.D. (Sheriff, 2005: 14). Slaves forged intimate relations in the Indian Ocean region within the household, court, administration or commerce, and learned the local languages which enhanced their prospects (Campbell, 2006: 312-313). Assimilation and social mobility following conversion took place within the Islamic World. Manumitting slaves was considered an act of charity and piety and it led to the transition of slaves to freedom and their integration to the host societies (Sheriff, 2015: 14-15). The pattern of social mobility consequent upon conversion was also true of the Portuguese. Speaking Portuguese and conversion to Roman Catholicism were prerequisites for assuming a Portuguese identity. Conversion to Islam, learning Arabic and Arab lore was a sine qua non for elite military slaves who made the transition from enslavement to positions of power within a single generation (de Silva Jayasuriya, 2015). Today, the Sidi elite remind us of their past prominent political role whilst the majority of Sidis remain marginalised due to lack of patronage by the Maharajahs and Nawabs whose fate changed with India's independence.

The African diaspora is posited in the frame of the Atlantic World where movement was linked to major economic activities and captives became a factor of input in a trade conducted between three Continents (Africa, America and Europe) across the Atlantic. But income from the Indian Ocean slave trade did not dominate the economy (Piketty, 2014: 158163). Migration eastwards cannot be viewed through the same lens, and a new conceptual 
framework is needed for Asia (de Silva Jayasuriya, 2018). Easterly African migrations are centuries old and histories are fragmented due to the long duration. Trade and Religion became interwoven with voluntary migration and slavery in ways which make it difficult to disentangle them. Following European intrusion in Indian Ocean commerce, the slave trade became a means of obtaining manpower to run imperial enterprises. Without a readily available supply of low cost labour, the high risk long distance spice trade would not have occurred. Colonisation was clearly an important phenomenon which drew upon captives to perform a myriad of tasks from building roads and fortresses to colonial armies. Trade routes, long-distance trade and empire building connected people globally, crossing cultures and introducing hybridity (de Silva Jayasuriya, 2017b). Quite apart from imperial demands, Africans were also concubines, missionaries, administrators, entertainers, sailors, politicians and state-builders.

Communities of Asians with African roots have become more visible in Dubai, India, Iraq, Iran, Israel, Maldives, Oman, Pakistan, Sri Lanka, Turkey and Yemen. These communities are guardians of their heritage and culture, however the concept of community in itself is problematic. The Intangible Cultural Heritage Convention defines a community as a network of people whose sense of identity or connectedness emerges from a shared historical relationship that is rooted in the practice and transmission of or engagement with their intangible cultural heritage (Curtis, 2010). Tim Curtis, Head of Culture, UNESCO Bangkok considers communities themselves as intangible heritage even though this represents a radical departure from previous practices.

In a global world in which economic interaction necessitates awareness of other peoples and other cultures, Afro-Asians cannot remain completely unnoticed. The nature and extent of cultural assimilation is a drawback to identifying Afro-Asians. Ethnic origins are blurred by overlapping physiognomic features. Skin colour is not a separator of ethnicities where intermarriage has occurred over centuries. Identification is also problematic where numbers are small and the wider politics favour other identities, which suggests that identity and diaspora should be considered together (de Silva Jayasuriya, 2009). Identity, usually based on shared belonging and differences, is crucial to understand individuals and their relationships with others, leads to artificial boundaries. Identity is dynamic and complex, and linked to a territory or homeland, family or kin and experience. Scholars and journalists, some of Afro-Asian descent themselves, are now seeking their long lost cousins scattered throughout the world. Subaltern voices are reaching a wider audience through films (Shroff 2004, de Silva Jayasuriya 2014). 
Amartya Sen (2001), the Economist-Philosopher and Nobel Laureate, cautions against the limitations of the presumption, often made implicitly, in identity politics and identitybased philosophy that a person belongs only to a single community or group. "African" and "Asian" are competing identities. Can anyone be both "African" and "Asian"? Afro-Asians are able to reconcile the two ethnicities. In the Gulf, people of African descent call themselves "Gulfricans", acknowledging their hybrid identity and otherness. Afro-Indians now assert that, "We're African and we're Indian" identifying with two geographical entities (Shroff, 2004). Self-identification is a key force and a growing factor as the diaspora begins to learn of their histories. The homeland is no longer imagined and a few Afro-Asians have visited Africa to perform their traditional music at festivals. Increased interaction between Afro-Asians and Africans has also heightened awareness of their ancestral land. Affinities in physiognomic features rekindle emotional ties with Africans and a desire to connect with their African kindred is observed. The disenfranchised status of Afro-Asians led to assumptions that diasporic consciousness was lacking. But field research has broken this false assumption; for example Afro-Sri Lankans are nationals of Sri Lanka and are entitled to all government benefits such as free education and free healthcare. Yet, a latent consciousness of another belonging emerges when they meet African visitors. But this must not be confused with a desire to return to Africa. When Sidis in the southern Indian State of Karnataka learnt of Nelson Mandela's visit to India through television and were too late to meet him in person, they wrote to the President and rejoiced when they received an acknowledgement from Mandela's office, as the Sidi leader of the Sidi Development Project (SDP) confirms.

Look this was the first time we Siddis (sic) contacted another African in Africa and the President came to know about our existence. By now he has forgotten about us but at least it is registered in his office that we Siddis in India exist and that we contacted him. (Camara, 2004: 110).

Sidis in North Karnataka and in Shaurashtra (Gujarat) have been officially recognised as socially and economically disadvantaged and have been empowered with Scheduled Tribe status under Article 342 of the Indian Constitution. 
342. (1) The President [may with respect to any State [or Union territory], and where it is a State, after consultation with the Governor thereof,] by public notification, specify the tribes or tribal communities or parts of or groups within tribes or tribal communities which shall for the purposes of this Constitution be deemed to be Scheduled Tribes in relation to that State [or Union territory, as the case may be].

(2) Parliament may by law include in or exclude from the list of Scheduled Tribes specified in a notification issued under clause (1) any tribe or tribal community or part of or group within any tribe or tribal community, but save as aforesaid a notification issued under the said clause shall not be varied by any subsequent notification" (The Constitution of India, 2015: 217).

Scheduled Tribe status entitles Sidis to benefit from assistance programmes which include reservation of places in educational institutions, jobs in government run services (railways, post office, and the police force), subsidies for housing and other forms of minor financial assistance. This is only the start of a process of Human Rights. As patrons of AfroAsians lost power due to political changes the Afro-Asians fell into an ethical vacuum (de Silva Jayasuriya, 2006a). Recognition is a prerequisite for meting out justice to a victim diaspora that emanated largely due to the slave trade. But there is a time lag before these empowered Sidis can realise their entitlements. Negotiating their way through powerful bureaucracies is a slow process, yet Sidi entrepreneurs and graduates have developed a sense of social responsibility and are searching for ways to give back something to their community. As lawyers, sociologists, entrepreneurs and founders of Non-Governmental Organisations emerge from the empowered Sidi communities, there is a trickle-down effect to those at the lower end of the social spectrum. Scheduled Tribe status is akin to positive discrimination in USA endowed on African-Americans as a pump-priming measure to break out of a vicious cycle (de Silva Jayasuriya, 2016: 21). Yet most Sidis persistently are under the social radar and attempts to redress past atrocities and injustices create new inequalities. Many more Sidis would like to be accorded this status, but currently it is not a political reality. Such status initiatives provide an incentive for groups to emphasise their "Sidiness". ${ }^{1}$

\footnotetext{
${ }^{1}$ See Catlin-Jairazabhoy and Alpers (2004) on Sidis in Gujarat and Karnataka.
} 


\section{A New Identity}

Within the historical records, Africans are conspicuous, even though anonymously, as brave, loyal and able soldiers (de Silva Jayasuriya, 2009). Afro-descendants are now claiming their heritage and negotiating a new identity, as they emerge from the peripheries expressing their strong cultural memories and carving out a niche for themselves in the diversity of Asia's culturalscape (de Silva Jayasuriya, 2015). Sidis today rarely speak about slavery, but its memory is evoked through material and symbolic links between Zanzibari ngoma and Sidi goma (Basu, 2008: 172). This connection is not surprising; Zanzibar was a main supplier of slaves to Gujarat. Sidi Goma, a group from Gujarat, has taken their music and dance to the world stage assisted by ethnomusicologists Nazir Jairazhabhoy and Amy CatlinJairazhabhoy. Since then, several Goma groups have sprung up and Sidis have performed in Europe, America, Africa, and Asia. While maintaining their traditional role as religious mendicants (faqirs), Sidis share their Sufi joy with others. Public performances have become a platform for embodying identity through music and dance (Catlin-Jairazabhoy, 2006: 19). Wearing animal skins and peacock headgear with painted bodies, the Sidi Goma perform a sacred traditional dance to the rhythm of the dhamal (small drum), madido (big drum), mugarman (footed-drum), mai mishra (coconut rattle), nafir (conch trumpet), malunga (braced musical bow) and other musical instruments. The death of a Muslim saint (Urs), for example, is celebrated over several days and provides an occasion for performing goma off the stage. Goma (from the KiSwahili word ngoma, meaning drum or dance) is both religious and secular and is a carryover from Africa.

Afro-Sri Lankans do not have any instruments that are akin to those played in Africa now; several generations were born in Sri Lanka. Raghavan (1962), the Sri Lankan ethnologist who visited the 'largest Afro-Sri Lankan community on the PuttalamAnuradhapura Road' reported that they played a braced musical bow. Emiliana, the eldest member of the Sirambiyadiya Afro-Sri Lankan community whom I first came into contact with whilst researching the contemporary status of Sri Lanka Portuguese told me that they had lived on the Puttalam-Anuradhapura road until they were given land in Sirambiyadiya. Raghavan's important observation links Afro-Sri Lankans to Sidis and to Africa, as the braced musical bow is an instrument played by Africans and Afro-diasporic communities. Moreover, the lyrics of manhas reveal diasporic consciousness. A song that I recorded during a field trip in 2013 which refers to negiri baila (African songs) illustrates this. The 
lyrics are in Sri Lanka Portuguese and the community has an idea of the theme and context of the songs but cannot give a word for word translation of it. I have used European/Standard Portuguese as an intermediary to extract the meaning; the majority of the lexicon in a creole language has its etyma in the base language - European Portuguese. The songs form a part of the oral tradition and I have used the Roman script here. The community does not use Sri Lanka Portuguese in its colloquial form but they do know some Creole words. Rasnayake (2007:76-77) lists forty-six words of Sri Lanka Portuguese that the community know. However, their vocabulary is larger than that as I found during my field research. ${ }^{2}$

\section{Cheru cheru tē minna Amoru chēru tē}

Chorus

Cheru cheru tē minna Amoru chēru tē

Amoru cheru te

Doce aroma, doce aroma

O cheiro do meu amor é doce

Amor de doce aroma

Sweet scent, sweet scent

The smell of my love is sweet

The smell of my love is sweet

Verse 1

Cheru cheru tē minna Amoru chēru tē

Rosa canta negiri baila amoru chēru te

Doce aroma, doce aroma

O cheiro do meu amor é doce

Rosa canta canções Africanas

Ela é o amor de doce aroma

Sweet scent, sweet scent,

The smell of my love is sweet

Rosa sings African songs

She is the love of sweet scent

Verse 2

Cheru cheru tē minna Amoru chēru tē

Rosa canta negiri baila fula chēru te
[Sri Lanka Portuguese: my transcription]

[Sri Lanka Portuguese: my transcription]

[Standard Portuguese: my translation]

[my translation]

[Sri Lanka Portuguese: my transcription]

[Standard Portuguese: my translation]

[my translation]

[Sri Lanka Portuguese: my transcription]

2 A linguistic survey of the community by Shihan de Silva Jayasuriya is in press. 
Doce aroma, doce aroma

O cheiro do meu amor é doce

[Standard Portuguese: my translation]

Rosa canta canções Africanas

Ela é o flor de doce aroma

Sweet scent, sweet scent,

The smell of my love is sweet

Rosa sings African songs

Ela is the flower of sweet scent

[my translation]

Verse 3

Cheru cheru tē minna Amoru chēru tē

[Sri Lanka Portuguese: my transcription]

Rosa canta negiri baila masmo chēru te

Doce aroma, doce aroma

O cheiro do meu amor é doce

[Standard Portuguese: my transcription]

Rosa canta canções Africanas

She é mesmo doce aroma

Sweet scent, sweet scent,

The smell of my love is sweet

Rosa sings African songs

She is the same sweet scent

Verse 4

Cheru cheru tē minna Amoru chēru tē

[Sri Lanka Portuguese: my transcription]

Rosa canta negiri baila rōsa chēru tē

[my translation]

Doce aroma, doce aroma

O cheiro do meu amor é doce

[Standard Portuguese: my translation]

Rosa canta canções Africanas

Rosa é doce aroma

Sweet scent, sweet scent,

The smell of my love is sweet

[my translation]

Rosa sings African songs

Rosa is of sweet scent

The music is produced with a combination of homemade ad hoc instruments coconut shells played against a piece of wood, metal spoons against metal vessels, glass 
bottle and a metal spoon - and local drums providing various resonances. The community have held on to their sense of polyrhythms and asymmetric rhythms. A "call and response" system where a lead singer and a chorus is identifiable also serves to mark out the manhas. Manhas were performed for their own in-group entertainment, but now a twelve-member band has been formed and performances at weddings and other occasions make them more visible. A few years ago, the band performed in Johannesburg, the only musicians representing Sri Lanka on her Independence Day celebrations in South Africa.

Afro-diasporists have influenced Sri Lankan popular music through genres called baila and kaffrinha which are sparked off by the syncopations (off beats) and cross rhythms (de Silva Jayasuriya, 2013). Kaffrinha is an Afro-Iberian form of music introduced to Sri Lanka by the Portuguese colonisers. Baila, on the other hand, is a form of music that evolved around Sri Lanka's independence embracing its new postcolonial identity. Manhas, characterised by polyrhythms and call and response, are distinct from kaffrinha and baila. Different features in these forms of music signal the layered histories of African migrations. Lyrics of manhas are in Sri Lanka Portuguese which was the lingua franca of the island for about three and a half centuries. The surveyor and writer, Richard Leslie Brohier (1973: 2730) describes the music of the Puttalam Afro-Sri Lankans in Sellan Kandel as kaffrinha and chikothi. There are no Afro-Sri Lankans in Sellan Kandel now. Kaffrinha and chikothi are forms of music that the pioneer researcher of Portuguese music in Sri Lanka, C M Fernando (1894) refers to. Ariyaratne $(1985,2001)$ refers to the missing score of the Bandmaster of the Ceylon Rifle Regiments, Herr Somers entitled, After Supper Kaffir Quadrille which is testimony to the significance of Africans to Sri Lankan musical life. As both the Afro-Sri Lankans and Portuguese Burghers (descendants of the Portuguese) were mother-tongue speakers of Sri Lanka Portuguese and Roman Catholics, there could have been commonalities in their musical repertoire. This remains an avenue for further research. From being mother-tongue speakers of Sri Lanka Portuguese - called Indo-Portuguese in the nineteenth century when linguists began to take an interest in Creole languages (de Silva Jayasuriya 1999), Afro-Sri Lankans have switched to Sinhala, the language spoken by the others in the village and also the language of instruction in the local schools which they attend; education at primary, secondary and tertiary levels are subsidised by government and all Sri Lankans are entitled to a 'free' education.

The legacy of African enslavement resonates in the forms of hybrid music and dance in the Atlantic: Samba, Salsa, Tango, Rhumba, Calypso, Reggae and numerous others are internationally known. The cross currents in the Indian Ocean and hybridised musical 
melanges such as Sega, Kaffrinha, Baila should also be widely known (de Silva Jayasuriya, 2006b).

\section{Concluding Remarks}

The rapidity of social mobility, rate of assimilation and the agency of Africans in shaping host societies through political, administrative, religious, cultural avenues all serve to characterise the eastern diaspora. Nevertheless, while the majority of Afro-Asians are powerless minorities, there exists a minority of empowered Afro-Asians who are important drivers and catalysts in the process of rectifying past injustices. African migrants in Asia should not be viewed through the same lens as those in the Atlantic. Diasporist narratives of their silenced histories play a crucial role in building a more comprehensive picture of the global African diaspora, and the key to unlocking demands for recognition must be channelled through a historical knowledge of these past events and crimes This, in itself, nonetheless, is not a sufficient condition for the development of marginalised Afro-Asian communities. Resistance to total conformity and the creation of an African homeland within displaced spaces through expressions of cultural memories differentiates Afro-diasporic communities from other communities in their hostlands. Performance knits communities together and builds collective identities and brings silenced histories to the fore expressing resistance through codes and symbols. Music, song and dance are symbolic of an African past. Even though migrations are centuries old and Africa thus is re-imagined, diasporic consciousness surfaces due to visits from African visitors to Asia. Oral histories and cultural retentions are useful tools in building a picture of what happened on the other side of Africa and revealing the hybrid identities of the diasporists.

\section{WORKS CITED}

ARIYARATNE, SUNIL (1985). An Enquiry into Baila and Kaffirinna (Sinhala text), Colombo: S Godage Brothers.

ARIYARATNE, SUNIL (2001). Baila Kaffirinna: An Investigation, E.A. Gamini Fonseka (translator). Colombo: S Godage Brothers. 
ALPERS, EDWARD (2003). "The African Diaspora in the Indian Ocean: a comparative perspective", in Shihan de Silva Jayasuriya and Richard Pankhurst (eds). The African Diaspora in the Indian Ocean, 19-50. New Jersey: Africa World Press.

BASU, HELENE (2008). "Music and the Formation of Sidi Identity in Western India". History Workshop Journal 65(1): 161-178. https://doi.org/10.1093/hwj/dbm069

BROHIER, RICHARD LESLIE (1973). Discovering Ceylon, (Colombo, 1973).

CAMARA, CHARLES (2004). "The Siddis of Uttara Kannada: History, Identity and Change among African Descendants in Contemporary Karnataka", in Sidis and Scholars, Amy Catlin-Jairazbhoy and Edward Alpers (eds). New Delhi: Rainbow Publishers.

CAMPBELL, GWYN. (2006). "The African-Asian Diaspora: Myth or Reality?" Shihan de Silva Jayasuriya and Jean-Pierre Angenot (eds), in The African Diaspora in Asia: Historical Gleanings, African \& Asian Studies 5 (3-4): 305-324. https://doi.org/10.1163/156920906779134795

CAPELA, JOSÉ (2002). O Tráfico de Escravos nos Portos de Moçambique 1733-1904. Porto: Edições Afrontamento.

CATLIN-JAIRAZHABHOY, AMY. (2006). "From Sufi shrines to the World Stage: Sidi African Indian Music Intervention and the Quest for 'Authenticity". Musiké 2: 124.

CATLIN-JAIRAZHABHOY, AMY \& ALPERS, EDWARD. (2004). Sidis and Scholars. Noida, India: Rainbow Publishers.

CURTIS, TIM (2010). Keynote speech at the International Seminar on the Safeguarding of Intangible Heritage: "Current Situations and Challenges on the Safeguarding Measures in the Asia-Pacific Region". Tokyo: National Research Institute for Cultural Properties.

DE SILVA, CHANDRA RICHARD (1972). The Portuguese in Ceylon 1617-1638. Colombo: H W Cave \& Company.

DE SILVA JAYASURIYA, SHIHAN (1999). "On the Indo-Portuguese of Ceylon: A Translation of a Hugo Schuchardt Manuscript". Portuguese Studies, 15, pp. 52-69. King's College, University of London.

DE SILVA JAYASURIYA, SHIHAN \& PANKHURST, RICHARD (2003) (eds). The African Diaspora in the Indian Ocean. New Jersey: Africa World Press.

DE SILVA JAYASURIYA, SHIHAN (2006a). "Trading on a Thalassic Network: African Migrations across the Indian Ocean". International Social Sciences Journal 188: 231240. https://doi.org/10.1111/j.1468-2451.2006.00613.x 
DE SILVA JAYASURIYA, SHIHAN (2006b). "Sounds of Identity: The Music of AfroAsians". Musiké. The Hague: Semar Publishers.

DE SILVA JAYASURIYA, SHIHAN (2008). The Portuguese in the East: A Cultural History of a Maritime Trading Empire. London: I B Tauris Academic Publishers.

DE SILVA JAYASURIYA, SHIHAN (2009). African Identity in Asia: Cultural Effects of Forced Migration. Princeton, New Jersey: Markus Wiener Publishers.

DE SILVA JAYASURIYA, SHIHAN (2010). The African Diaspora in Asian Trade Routes and Cultural Memories. UK: Edwin Mellen Press.

DE SILVA JAYASURIYA, SHIHAN (2013). "Postcolonial Innovations in Sri Lankan Popular Music: Dynamics of Kaffrinha and Baila". International Journal of the Institute of Ethnic Studies Sri Lanka II: 1: 1-29.

DE SILVA JAYASURIYA, SHIHAN (2014). Indian Ocean Memories: African Migrations (documentary film).

DE SILVA JAYASURIYA, SHIHAN (2015). "Indians of African Descent: Emerging Roles and New Identities". Journal of African Diaspora Archaeology \& Heritage 4(1):118. https://doi.org/10.1179/2161944114Z.00000000019

DE SILVA JAYASURIYA, SHIHAN (2016). "Indian Ocean African Migrants: Difference and Inequalities". Katsuhiko Kitagawa (ed). African and Asia Entanglements in Past and Present: Bridging between History and Development Studies. Kansai: University of Kansai.

DE SILVA JAYASURIYA, SHIHAN (2017a). "East India Company Stopovers in Madagascar: A Stepping Stone in the Indian Ocean". Land and Maritime Empires in the Western Indian Ocean (with Beatrice Nicolini). Milan: Educatt, Università Cattolica.

DE SILVA JAYASURIYA, SHIHAN (2017b). "Unexpected Outcomes of the Portuguese Encounter in Sri Lanka: Innovation and Hybridity", in Chaos in the Contact Zone. Unpredictability, Improvisation and the Struggle for Control. Stephanie Wodianka, ed. Transcript, Bielefeld.

DE SILVA JAYASURIYA, SHIHAN (2018 in press). "African diaspora in Asia: A Theoretical Perspective, in Carole Boyce-Davis (ed), UNESCO General History of Africa: African Diaspora Volume Epistemological Section. Paris: UNESCO.

FERNANDO, C M (1894). "The Music of Ceylon", Journal of the Royal Asiatic Society (Ceylon) XIII: 83-89.

GERBEAU, HUBERT (1978). "The Slave Trade in the Indian Ocean: Problems Facing the Historian and Research to be Undertaken", in The African Slave Trade from the Fifteenth to the Nineteenth Century. Paris: UNESCO. 
GOONATILLAKA, MIGUEL (1983). An interview with the Portuguese speaking community in Puttalam, Sri Lanka, Colombo, National Archives.

HARRIS, JOSEPH E (2003). "Expanding the Scope of African Diaspora Studies: The Middle East and India, a Research Agenda", Radical History Review 87: 157-168. https://doi.org/10.1215/01636545-2003-87-157

McLEOD, JOHN (2008). "Marriage and Identity among the Sidis of Janjira and Sachin" in $\mathrm{J}$ C Hawley (ed). India in Africa, Africa in India. Indian Ocean Cosmopolitanisms. Bloomington: Indiana University Press.

PIKETTY, THOMAS (2014). Capital in the Twenty-First Century: the Dynamics of Inequality, Wealth, and Growth. The Belknap Press of Harvard University Press. https://doi.org/10.4159/9780674369542

RAGHAVAN, M D (1962). Ceylon: a Pictorial Survey of the Peoples and Arts. Colombo, M.D. Gunasena.

RASNAYAKE, SANDAMALI (2007). Sri Lankāve Vesene Kāpiri Janathāve (Sinhala text). Colombo: S Godage.

ROBBINS, KENNETH \& McLEOD, JOHN (eds) (2006). African Elites in India. India: Mapin Publishers, India.

SEN, AMARTYA (2001). Other People. London: The British Academy.

SHERIFF, ABDUL (2005). "Slave Trade and Slave Routes of the East African Coast", in Slave Routes and Oral Tradition in Southeastern Africa. Benigna Zimba, Edward Alpers \& Alan Isaacman (eds). Maputo: Filsom Entertainment lds.

SHROFF, BEHEROZE (2004). We're Indian and African: Voices of the Sidis. (film).

THE CONSTITUTION OF INDIA (2015). New Delhi: Government of India Ministry of Law and Justice (Legislative Department).

YULE, HENRY (1903). Hobson-Jobson: A Glossary of Colloquial Anglo-Indian Words and Phrases and of kindred terms, etymological, historical, geographical and discursive. William Crooke (ed). London: John Murray.

SHIHAN DE SILVA is Senior Fellow at the Institute of Commonwealth Studies, University of London. 